\title{
Vaktaalrubriek
}

\section{Terminologie met betrekking tot kernmateriaalwaarborge}

\author{
N. von Wielligh en J.S. Maritz \\ Departement Kern-nie-proliferasie, Atoomenergiekorporasie, Posbus 582, Pretoria, 0001
}

W. van Z. de Villiers*

Departement Kerntegnologie, Atoomenergiekorporasie, Posbus 582, Pretoria, 0001

*(Outeur aan wie korrespondensie gerig kan word.

Sedert die ontstaan van die Suid-Afrikaanse kernbedryf met die stigting van die Raad op Atoomkrag (RAK) in 1948, maar veral vanaf 1959 , toe met 'n omvattende navorsingsprogram begin is, was daar 'n behoefte aan Afrikaanse terminologie vir dié snel groeiende vakgebied. 'n Vaktaalkomitee bestaande uit personeellede van die RAK en die Vaktaalburo van die Suid-Afrikaanse Akademie vir Wetenskap en Kuns is in 1966 in die lewe geroep. Die komitee se werk het uitgeloop op die publikasie van 'n tweetalige lys kernenergieterme deur die SA Akademie in 1976. Dit is opgevolg met 'n omvattende Kernbedryfwoordeboek (in twee dele), wat in 1990 deur die Atoomenergiekorporasie (AEK) gepubliseer is.

'n Spesifieke subvakgebied in die kernbedryf het te doen met 'n internasionale stelsel vir die verifiëring van kernmateriaal om die gebruik daarvan vir die vervaardiging van kernwapens te voorkom. Die basis hiervan is die Statuut van die Internasionale Atoomenergieagentskap (IAEA), asook die bekende Treaty on the Non-Proliferation of Nuclear Weapons, kortweg die NonProliferation Treaty, wat in Afrikaans as die Kernsperverdrag bekend staan. Wanneer 'n land hierdie verdrag onderteken, stem hy in tot die aangaan van 'n waarborge-ooreenkoms met die IAEA. Hiervolgens moet die staat 'n meganisme instel om kloofbare kernmateriaal te beheer en aan die IAEA oor alle bewegings van sodanige materiaal verslag te doen. Die IAEA het die reg om deur inspeksies die verslae van die staat te verifieer. Dié verifiëringstelsel staan bekend as kernmateriaalwaarborge. Die SAFARI-1-navorsingsreaktor op Pelindaba en die Koebergkernkragstasie naby Kaapstad was sedert onderskeidelik 1967 en 1977 aan waarborge onderworpe, maar Suid-A frika het eers in 1991 tot die Kernsperverdrag toegetree.

Soos verwag kon word, het 'n eie vakterminologie ten opsigte van waarborge ontwikkel. Trouens, die IAEA het in 1987 'n glossarium' gepubliseer waarin definisies van 329 terme op dié gebied asook vertaalekwivalente in ses tale (Engels, Frans, Russies, Spaans, Duits, Japannees) gegee is. Die doel van hierdie artikel is om Afrikaanse terminologie op die gebied van kernmateriaalwaarborge wat tans algemeen by die AEK en elders in Suid-Afrika gebruik word, bekend te stel (sien tabel). Dit is interessant om daarop te let dat slegs enkele van hierdie terme in die 1976-lys van kernenergieterme voorkom, waarskynlik omdat slegs een fasiliteit in Suid-Afrika destyds aan waarborge onderworpe was. Sowat $40 \%$ van die terme verskyn wel in die Kernbedryfwoordeboek (1990). Die res het eers in algemene gebruik gekom ná Suid-Afrika se toetrede tot die Kernsperverdrag, wat kernmateriaalbeheer en rekenskap op staats- en fasiliteitsvlak sterk na vore gebring het.

Daar is ' $n$ aantal opvallende verskille tussen die Afrikaanse terme in die Kernbedryfwoordeboek en dié waaraan tans voorkeur gegee word. Dit word uitgewys en bespreek in die notas onderaan die tabel, waar ook toeligting oor die vertaling

van enkele ander terme verskaf word.

\section{Engels}

access for inspection

accidental gain

accidental loss

accounting record

accounting report

ad hoc inspection

adjusted book value

advance notification

anomaly

assay $n$.

batch

book inventory

bulk facility

bulk handling facility

category change

completeness

comprehensive safeguards

agreement

concise note

containment

country code

cut-off time

design information

questionnaire

direct-use material

discrepancy

diversion

diversion strategy

domestic

element code

exempted nuclear material

exemption

facility activities

facility attachment

facility code

facility level

feedback

fissionable material

general ledger

header

header date

header information

initial inspection

initial report

inspection goal

\author{
Afrikaans \\ Nota \\ inspeksietoegang \\ toevallige wins \\ toevallige verlies \\ rekenskaprekord \\ rekenskapverslag \\ ad hoc-inspeksie \\ aangepaste boekwaarde \\ voorafkennisgewing \\ afwyking, anomalie \\ bepaling \\ lot \\ boekvoorraad \\ grootmaathanterings- \\ fasiliteit, massa- \\ kategorieverandering \\ volledigheid \\ omvattende waarborge- \\ ooreenkoms \\ kort nota \\ inperking \\ landkode \\ spertyd \\ ontwerpinligtingsvraelys
}

regstreeks bruikbare materiaal teenstrydigheid

wegwending

wegwendingstrategie

binnelands, plaaslik, intern

elementkode

vrygestelde kernmateriaal

vrystelling

fasiliteitsaktiwiteite

fasiliteitsbylaag, fasiliteitsbylae

fasiliteitskode

fasiliteitsvlak

terugvoer

kloofbare materiaal

algemene grootboek

opskrif

opskrifdatum

opskrifinligting

aanvangsinspeksie, begininspeksie aanvangsverslag, beginverslag

inspeksiedoelwit 
inspection schedule international safeguards inventory

inventory change report inventory listing inventory listing format inventory taking inventory verification item count item facility

key measurement point locations outside facilities matching

material balance material balance area material balance period material balance report material description code material flow material unaccounted for measured discard non-nuclear material non-proliferation non-proliferation treaty nuclear material accounting nuclear material accounting officer

nuclear material control nuclear material inventory nuclear material reporting

nuclear non-proliferation operating record operating report peaceful use physical beginning physical ending physical inventory physical inventory listing physical inventory taking physical inventory

verification

re-application

rebatching

reporting

reporting activity

reporting format

reporting function

retained waste

routine inspection

safeguards

safeguards agreement safeguards implementation safeguards implementation officer

safeguards implementation report

safeguards inspection

safeguards inspector

shipper/receiver difference significant quantity source data special inspection inspeksieskedule

internasionale waarborge

voorraad

voorraadveranderingsverslag 3

voorraadlys

voorraadlysformaat

voorraadneming

voorraadverifiëring

itemtelling

itemfasiliteit

sleutelmeetpunt

gebiede buite fasiliteite

passing

materiaalbalans

materiaalbalansarea, -gebied

materiaalbalansperiode

materiaalbalansverslag

materiaalbeskrywingskode

materiaalvloei

onverantwoordbare materiaal

afgemete wegdoening

8

nie-kernmateriaal

nie-proliferasie

9,10

kernsperverdrag

kernmateriaalrekenskap

kernmateriaalrekenskap-

beampte

kernmateriaalbeheer

kernmateriaalvoorraad

kernmateriaalverslagdoening, -gewing

kern-nie-proliferasie

9

bedryfsrekord

bedryfsverslag

vredesgebruik

beginvoorraad

eindvoorraad

fisiese voorraad

fisiesevoorraadlys

fisiesevoorraadneming

fisiesevoorraadverifiëring

hertoepassing

lotverandering

verslagdoening, verslaggewing II

verslagdoeningsaktiwiteit II

verslagdoeningsformaat 11

verslagdoeningsfunksie 1

retensie-afval

roetine-inspeksie

waarborge

waarborge-ooreenkoms

waarborge-implementering

waarborge-implementerings-

beampte

waarborge-implementeringsverslag

waarborge-inspeksie

waarborge-inspekteur

versender-ontvanger-verskil

beduidende hoeveelheid

brondata

spesiale inspeksie spent fuel

starting point

state level

state system of accounting

and control

stratum

subsidiary arrangement

surveillance

tag check

termination

timeliness criteria

timeliness goal

traceability

unannounced inspection

voluntary offer agreement gebruikte brandstof

beginpunt

staatsvlak

staatstelsel vir rekenskap

en beheer

stratum

aanvullende reëling

bewaking

nagaan van etiket

beëindiging

tydigheidskriteria

tydigheidsdoelwit

naspeurbaarheid

verrassingsinspeksie

vrywillige-aanbodooreenkoms

\section{NOTAS:}

1. Accounting word nou deurgaans as rekenskap vertaal (na analogie van rekenpligtigheid, waarmee dit vergelyk kan word), in teenstelling met die inkonsekwente gebruik van verantwoording en verrekening in verskillende naamwoordelike samestellings in die Kernbedryfwoordeboek. Eersgenoemde Afrikaanse term word ook beskou as meer geskik vir "the activities carried out to establish the quantities of nuclear material present in defined areas and the changes in those quantities within defined periods."' Dit moet verder duidelik die verskil met die vakgebied rekeningkunde uitwys Daarbenewens is die term verrekeningstaat in die Kernbedry fwoordeboek (vir accounting record) nie korrek nie. aangesien daar 'n duidelike verskil tussen 'n rekord en 'n staat is.

2. Die term assay word in verskeie vakgebiede en in redelik uiteenlopende toepassings gebruik. Dit word vertaal as toets, bepaling of smelttoets (Terblanche se Tegniese Woordeboek en Bosman, Van der Merwe en Hiemstra se Tweetalige Woordeboek) asook essai of essaiëring (Tegniese Woordeboek en die Nuwe Chemiewoordeboek). In die konteks van waarborge, waar assay gedefinieer word as "a measurement which establishes the total quantity and composition of nuclear material present in the items being measured", ' word hepaling verkies.

3. As Afrikaans vir inventory word voorraad in bostaande tabel gebruik, maar imentaris is ook korrek. In aansluiting daarby is die Kernbedryfwoordeboek se kunsmatige inventariswisselverslag vir inventory change report in die praktyk deur voorraduderanderingsverslag vervang.

4. Die term bulk word in hierdie konteks meestal as grootmaatvertaal. Die gebruik van massa- is egter ook korrek, soos byvoorbeeld in al drie bogenoemde woordeboeke angedui word. Massa kan egter soms verwarring tussen bulk en mass meebring.

5. Die Engelse terme is hier verwarrend, aangesien (physical) inventory listing na 'n dokument verwys, maar (physical) inventory taking en - verification na aktiwiteite; vandaar die onderskeie Afrikaanse terme. Let ook op die Afrikaanse skryfwyse van die samestellings, wat daarop dui dat fisiese op voorraad betrekking het.

6. Matching is in die Kernbedryfwoordeboek as aanpassing vertaal; dit moet egter passing wees.

7. Vir gemak van uitruilbaarheid van Engelse en Afrikaanse afkortings word materiaalbalansarea nou verkies bo materiaalbalansgebied, wat in die 1990-woordeboek aangegee is, hoewel laasgenoemde natuurlik nie verkeerd is nie.

8. Die term measured discard word gedefinieer as "nuclear 
material which has been ... disposed of in such a way that it is not suitable for further nuclear use."' In dié konteks word wegdoening as 'n meer geskikte vertaling as afval of skroot beskou. Laasgenoemde word wel deur verskeie woordeboeke as Afrikans vir discard aangegee.

9. Die A frikaanse woordelys en spelreëls (Agste uitgawe, 1991) beveel aan dat samestellings met nie-vas geskryf moet word, maar laat ruimte vir uitsonderings in gevalle waar dit gebruiklik geword het om 'n koppelteken te gebruik. Koppeltekens word uiteraard ook gebruik om leesbaarheid van samestellings te verhoog. Om hierdie redes word die skryfwyse nie-proliferasie en kern-nie-proliferasie verkies. Ter wille van konsekwentheid binne die vakgebied wat hier ter sprake is, word soortgelyke samestellings in bostaande tabel, soos in die Kernbedryfwoordeboek, met koppeltekens geskryf.

10. Die Kernbedryfwoordeboek se ietwat kunsmatige (maar beskrywende) nie-vermeniguldiging vir non-proliferation is in die praktyk deur nie-proliferasie vervang ter wille van groter herkenbaarheid in 'n omgewing waar die amptelike IAEA-verslagtaal Engels is. In dié verband is dit interessant dat die Afrikaans sperverdrag vanaf die Duits Sperrvertrag ingang gevind het, waarskynlik danksy die bondigheid daar- van. Daarenteen het nie-vermenigvuldiging, met die betekenis van nie-verspreiding (vanaf die Duitse sinoniem vir genoemde verdrag, naamlik Nichtverbreitungsvertrag), die knie gebuig voor die Engelsklinkende nie-proliferasie.

11. Die gebruik van verslagdoening of verslaggewing vir reporting is ' $n$ kwessie van persoonlik voorkeur.

12. Let daarop dat die solidus in hierdie tipe samestellings in A frikaans net gebruik word waar daar 'n. getalle- of wiskundige verhouding tussen die komponente van die samestelling is; vandaar die skryfwyse met koppeltekens in hierdie geval.

13. Die Afrikaanse term onáfgekondigde inspeksie kan moontlik 'n beter (direkte) vertaling geag word vir dié tipe inspeksie, wat sonder voorafkennisgewing uitgevoer word. Die aangeduide term is egter korter en dra die betekenis goed oor.

Lesers se kommentaar op enige aspek van bogenoemde sal waardeer word.

\section{LITERATUURVERWYSING}

1. IAEA Safeguards: Glossary (1987). International Atomic Energy Agency, Vienna. 